\title{
Evolutions and structural changes in secondary vocational education in Romania during the last three decades
}

\author{
Marian Zaharia ${ }^{1}$, Aniela Bălăcescu ${ }^{2}$ \\ 1 Association for Democracy, Education, Respect, Targu-Jiu, Romania \\ 2 "Constantin Brancuşi”" University of Targu-Jiu, Romania \\ E-mail: marianzaharia53@gmail.com, anielabalacescu@yahoo.com
}

\begin{abstract}
The study focused on capitalizing on the data provided by the National Institute of Statistics of Romania to outline the amplitude of secondary vocational education, its characteristics and the identification of disparities at regional level. The research carried out within this approach uses a methodology based on regression models that captures the changes that have occurred in the evolution of the investigated phenomenon. The study can be support in the formulation of suitable educational policies.
\end{abstract}

Keywords: education levels, secondary vocational education, development regions, Romania

\section{Introduction}

The continuous development of the economic and social systems, the transition to the knowledgebased economy and the continuous diversification of the labor market requirements, create continuous pressures on the educational systems, both in terms of the applicability of the knowledge provided and in ensuring the compatibility between the national educational systems. Under the conditions of globalization, education systems must be directly linked to the labor market [1] so as to build skills and abilities for future members of society [2], which will lead to sustainable economic and social development $[3,4]$.

Viewed from the point of view of systems theory, education and economics are two open systems that are interconditioned [5]. The connections between them must function in such a way as to produce positive effects in both, in the sense that economic development must stimulate the development of education system, in general and also the vocational education, and this will provide a trained workforce that will produce economic development.

Although secondary vocational education, a few decades ago, was considered inferior compared to general secondary education [6], starting with the last decade of the last century, its role in the formation of the workforce is beginning to be reconsidered [7]. Furthermore, in the study, Silliman and Virtanen [8] point out that the graduates of secondary vocational education have a higher competitive advantage in the labor market compared to those with general secondary education level.

The development of secondary vocational education is closely linked to the need to change and adapt educational systems to the needs of economic and social development [9], all the more so, as this is in direct connection with the economy and the business world, education oriented in this sense, being a key factor in sustainable development, social mobility and raising the standard of living [10].

At the level of European educational policies, by signing in 2002 the Copenhagen Declaration on strengthening European cooperation in vocational training, favorable premises have been created for the compatibility of the national educational process with the tendencies and good practices used in 
the EU Member States. The measures of reform of vocational education were also supported by the implementation of numerous projects carried out within the PHARE program [11].

In Romania, the high school education fields were defined by the Education Law no. 84 of July 24 , 1995 [12] which stated in Art. 24. - (1) that "high school education works, as a rule, with the following profiles: theoretically - real and humanist -, informational, pedagogical, technical, economic, administrative, agricultural, forest, agro mountain, military, art, sports and theology". This law was amended and supplemented by Government Ordinance no. 151/1997 that reformulates Art. 24. - (1) defining the following fields and profiles: "a) the theoretical profile with the humanist and real profiles; b) the technological profile with the technical profiles, services, exploitation of natural resources and environmental protection; c) vocational profile with military, theological, sports, artistic and pedagogical profiles".

In the context of the ones outlined above, the paper aims to identify and highlight the main structural and dynamic characteristics of vocational secondary education in Romania, as organized by law 84/1995 and subsequent amendments and completions, the period under review being 1997- 2018.

The paper was structured in four sections, as follows: this introduction, the second section describes the research methodology, respectively the identification of variables used to analyze the evolutions of vocational education in Romania, the use and testing of regression models for variable analysis, section 3 presents the results of the tests and their interpretation, and the last section was dedicated to the general conclusions.

\section{Methodology}

The data series used in the analysis of the evolutions of vocational education in Romania are based on the series of data available in NIS databases [13]. The main data sources were constituted by the data series on enrolled population, by level of education, gender, macro regions, development regions and counties [14] in 1997-2018 period. Of these, in accordance with ISCED [15] and the Law of National Education Law 1/2011 [16], were extracted the data series regarding the evolution of the number of students enrolled in high school education, in the profiles: military, theological, sports, artistic and pedagogical. Starting from this, six main indicators were defined (Table 1).

Table 1. The variables used to analyze the evolutions of vocational education in Romania

\begin{tabular}{llc} 
Indicator & \multicolumn{1}{c}{ Significance } & Units \\
\hline SVE & Students enrolled in vocational education & number \\
SNE & Students enrolled in normal schools (Pedagogical High Education) & number \\
SAP & Students enrolled in high schools with artistic profile & number \\
SPES & Students enrolled in high schools with a physical education and sports program & number \\
SMS & Students enrolled in military high school & number \\
STS & Students enrolled in theological seminars & number
\end{tabular}

To identify the characteristics of the evolution of the variables in the period included in the analysis, as well as for their analysis, regression models were used, of the form:

$$
Y(t)=a+\sum_{k=1}^{m} b_{k} \cdot t^{k}+\varepsilon, \quad t \in[1, n]
$$

In (1), the parameters $a, b_{k} \in \mathfrak{R}, k=\overline{1, m}, m$ is the order of the polynomial model and $n$ represents the number of time points of the analyzed series. 
Testing the validity of the models (1) was performed using the ANOVA methodology [17], and the evaluation of the quality of the estimates was carried out with the correlation ratio (R), and the coefficient of determination $\left(\mathrm{R}^{2}\right)$. The null hypothesis of test $\mathrm{F}$ is:

$\mathrm{HM}_{0}$ : the model is not statistically significant ( $F_{c a l c}<F_{\alpha, k, n-k-1}$ or Sig.F $>\alpha$ ).

Testing the statistical meanings of the model parameters (1) was performed using the bilateral $t$ (Student) test, whose null hypothesis is:

$\mathrm{HP}_{0}$ : the parameter $b_{k}$ and / or $a$ does not differ significantly from zero; is not statistically significant $\left(t_{\text {calc }}<t_{\alpha / 2, n-k-1}\right.$ or Sig.t $\left.>\alpha\right)$.

The identification of the models (1), as well as the testing of their statistical significance, and of their parameters, were performed using SPSS, for Confidence level 95\% (significance level $\alpha=0.05$ ).

\section{Results and discussions}

Between 1997 and 2018, the evolution of vocational education in Romania is characterized by a series of particularities at the level of each of the five profiles, both in terms of the number of students enrolled and the weightings of the profiles as a whole.

\subsection{Evolutions of vocational education in Romania}

In Romania, between 1997 and 2018, the number of students enrolled in secondary vocational education (SVE) had an oscillating evolution (Figure 1), both at the general level and at the level of the development regions, determined on the one hand by the changes in structure of the education system, and on the other hand by the demographic dynamics.

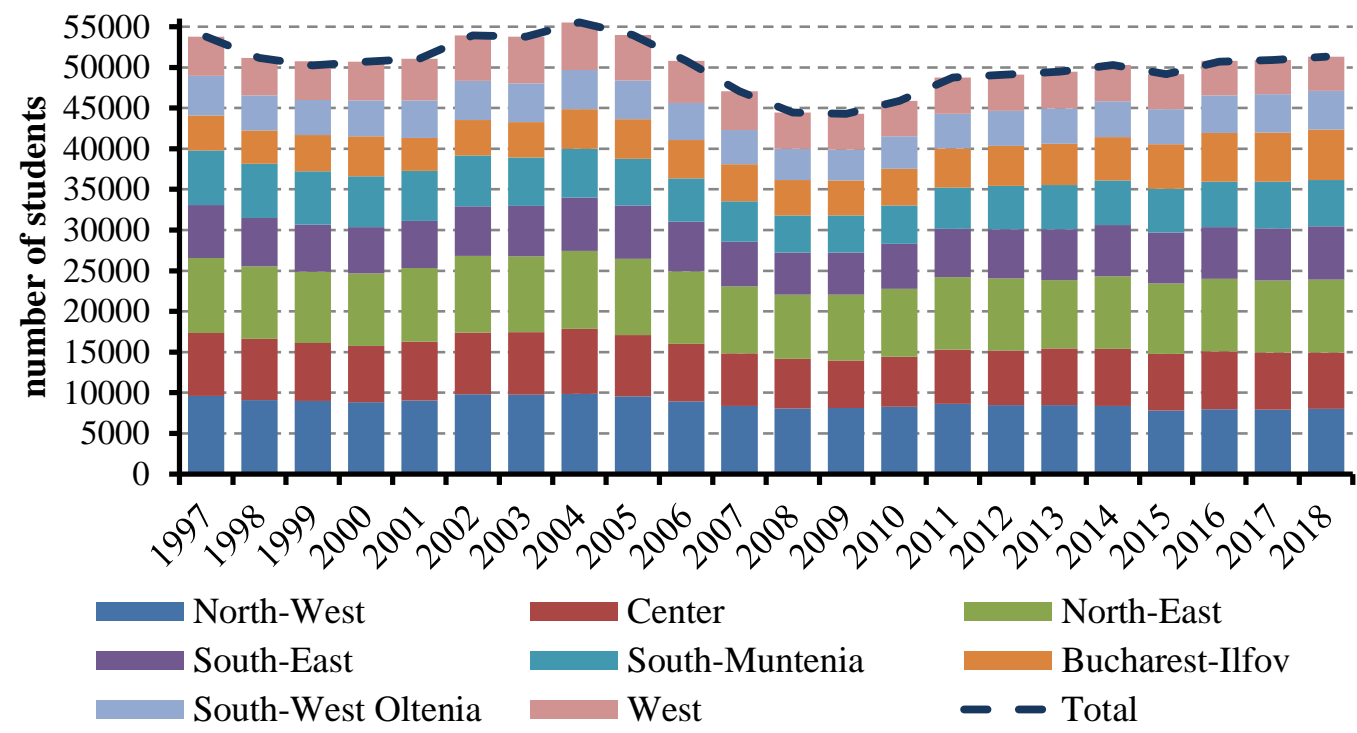

Figure 1. Evolutions of the number of students enrolled in vocational education in 1997-2018 period

During the analyzed period, the number of students enrolled in secondary vocational education has some variations depending on the periods. Thus, it can be seen that the number of students enrolled in secondary vocational education registered slight decreases during the periods 1997-1999, 2005-2009, and increases were registered during the periods 2000-2004, 2010-2018.

Starting with the 2009/2010 school year, the measure of increasing the number of schooling in high school education was applied, as a result of taking over the places of the SAM (school of arts and 
crafts) type of education, thus significantly increasing the number of pupils. enrolled in secondary and vocational education, respectively [18].

If in 1997, 53753 students were included in secondary vocational education, at the end of the period analyzed, in 2018 at this educational level there were 51323 students, representing a decrease of $4.5 \%$, due in particular to the decrease of the school population.

In territorial profile, the evolution of the students from secondary vocational education had the same irregular dynamics, as at national level. It should be noted that if at the beginning of the period analyzed, most of the students enrolled are in the North-West region (9197 students), at the end of the period, this region is surpassed by the North-East Region, which has a number of 8956 students compared to 8017 existing students in the North West Region. The West Region is characterized by a low level of students enrolled in secondary vocational education compared to the other regions.

Regarding the share of the students enrolled in the secondary vocational education out of the total of the students enrolled in the secondary education, at the level of the regions it is possible to find a concave trajectory during the analyzed period. (Figure 2), with a significant decrease in the period 2005-2010 determined by the decrease of the school population and the educational reforms.

The increase of the number of students attending secondary vocational education in the last eight years is explained by the fact that this route has become an attractive option, given that it offers the student qualifications for which there are opportunities in the labor market.

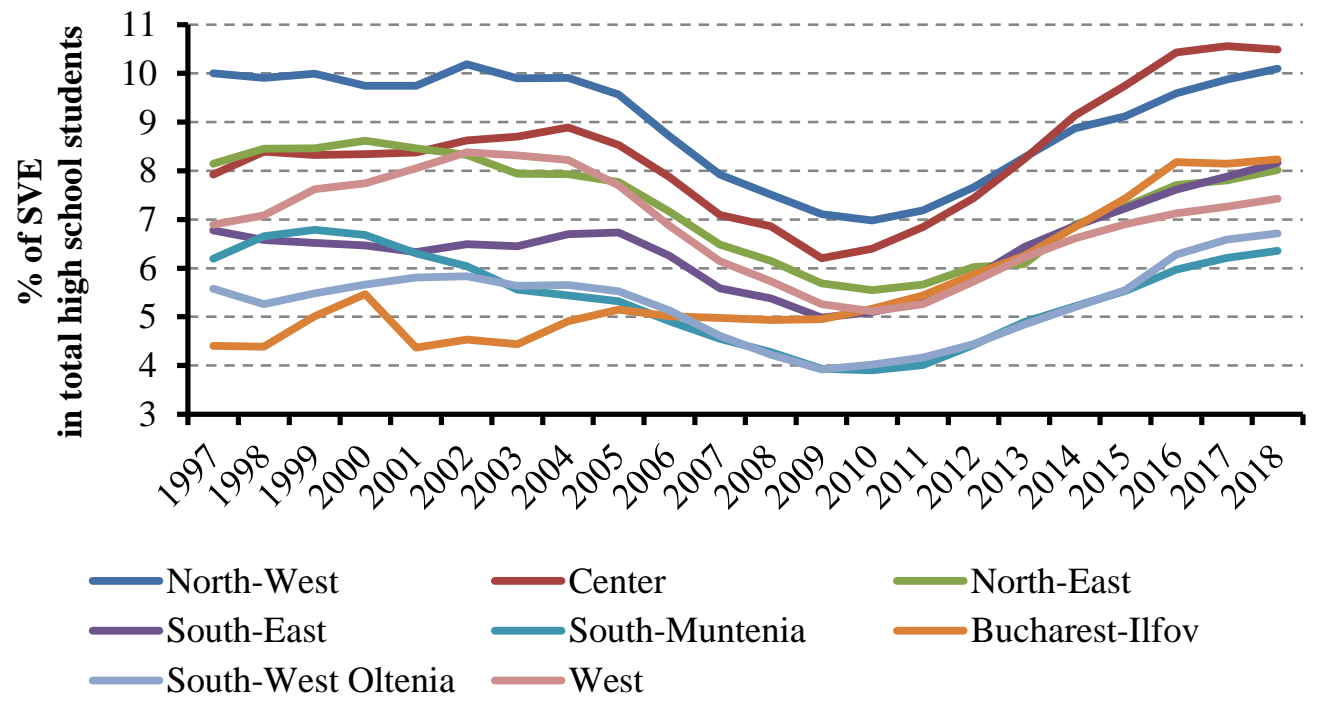

Figure 2. The changes of the shares of students enrolled in vocational education (SVE) in the total of students enrolled in high school in 1997-2018 period

If at the beginning of the period, the highest rate of inclusion in secondary vocational education existed in the North-West Region (10.0\%) at the opposite pole being the Bucharest Ilfov region $(4.4 \%)$, at the end of the analyzed period, at the top of the ranking will be found Center Region (10.49\%), and the last place is South-Muntenia Region (6.35\%)

It is worth noting that for Bucharest-Ilfov Region, the evolution of secondary vocational education was on a different trend compared to the other regions during the period under analysis. Thus, if in 2005, most of the regions recorded significant decreases in the weight of students enrolled in secondary vocational education (SVE) in the total of students enrolled in high school, except Bucharest Ilfov (increase compared to the previous year by 0.24 percentage points) and the region South-East (up from the previous year by 0.03 percentage points).

From 2010 there is an increase in the number of students attending secondary vocational education at both national and regional level, with a more pronounced growth rate for Bucharest-Ilfov Region 
(with a share of students enrolled in secondary vocational education in total students registered in high school in 2018 by $8.23 \%$ ), North-West Region $(10.10 \%)$ and Center Region $(10.49 \%)$. The region that registered at the end of the analyzed period the lowest weight of the students who opted for the profiles in the vocational sector was South-Muntenia (6.35\%)

The analysis of participation in secondary vocational education on training profiles in the period $1997-2018$ is shown in figure 3.

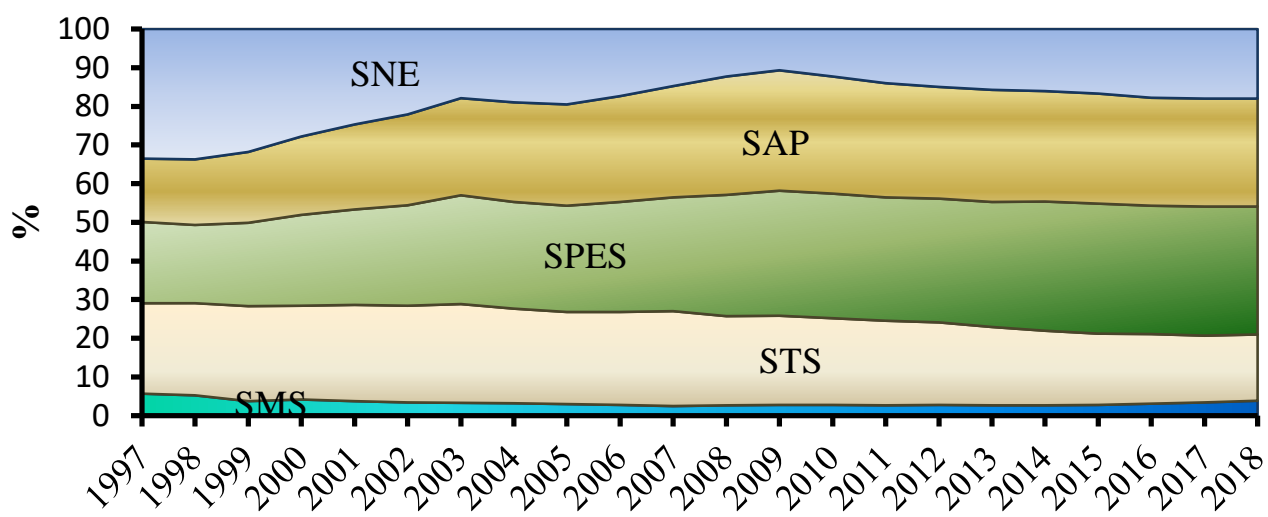

Figure 3. Evolutions of the shares of educational profiles, in total students enroled in secondary vocational education in $1997-2018$ period

On average, during the period analyzed 1997-2018, the highest shares are noted for Students enrolled in high schools with a physical education and sports program (SPES - 28.94\%), followed by Students enrolled in high schools with artistic profile (SAP - 25.94\%), Students enrolled in theological seminars (STS-22.30\%), Students enrolled in normal schools Pedagogical High Education (SNE$19.49 \%$ ) and Students enrolled in military high school (SMS) - 3.32\%).

\subsection{Pedagogical High Education}

The evolution of the number of students enrolled in normal schools in 1997-2018 is generally similar to that recorded in secondary vocational education, with variations of increases and decreases as can be seen in figure 4 .

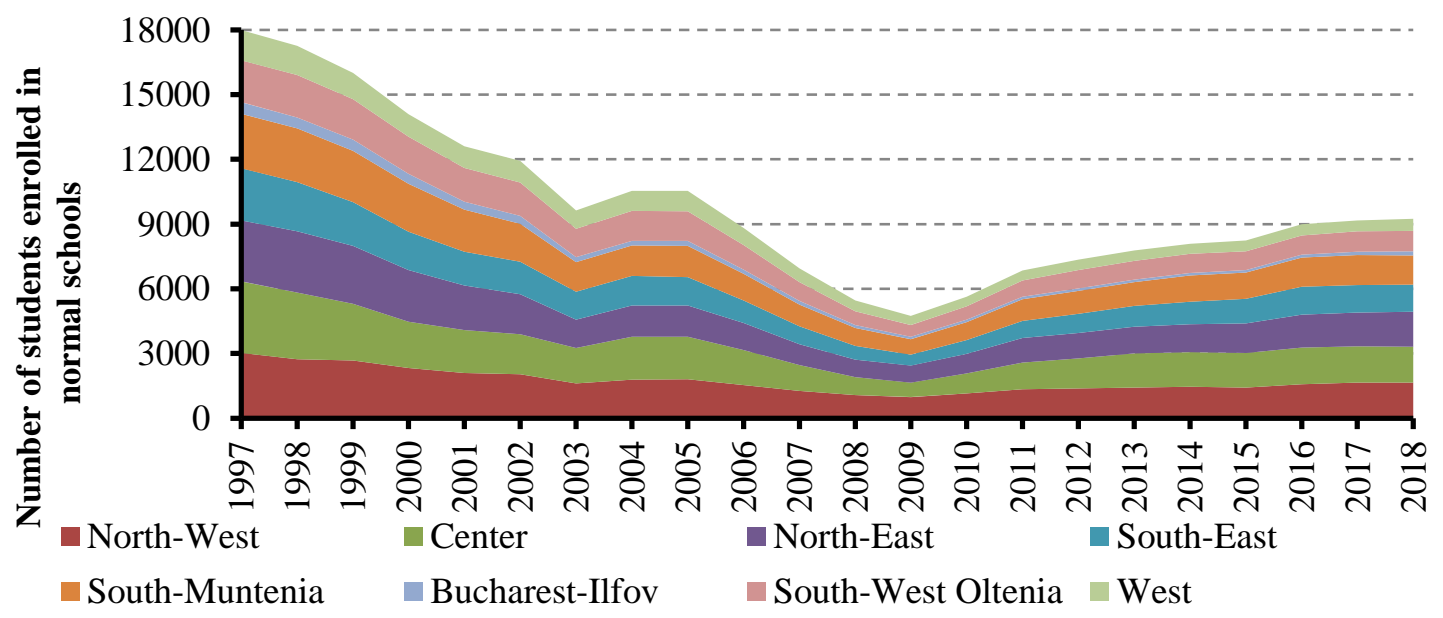

Figure 4. Evolutions of the number of students enrolled in normal schools in 1997-2018 period

The lowest value of the number of students enrolled in normal schools in 1997-2018 was recorded in 2010 (109 students) in Bucharest-Ilfov, and the highest value was recorded in 1997 (3312 students) 
in the Center Region. Unfortunately, the next 12 years were characterized by a decrease in the number of students enrolled in normal schools in all regions, and during 2010-2018, there was a growing trend, but below the level recorded at the beginning of the analyzed period.

As against of 1997, in 2018 there were no significant changes in the share of students enrolled in pedagogical high schools by development regions (figure 5). In 2018, the minimum values of the share of students enrolled in pedagogical high schools were registered in Bucharest-Ilfov Region (2\%), and the maximum values were registered in North-West Region (18\%) and Center Region (18\%). . Between the two values of minimum and maximum, the regional hierarchy according to the share of students enrolled in pedagogical high schools was: North-East (17\%), South-Muntenia (15\%), SouthEast (14\%), South-West Oltenia (10\%), West (6\%).

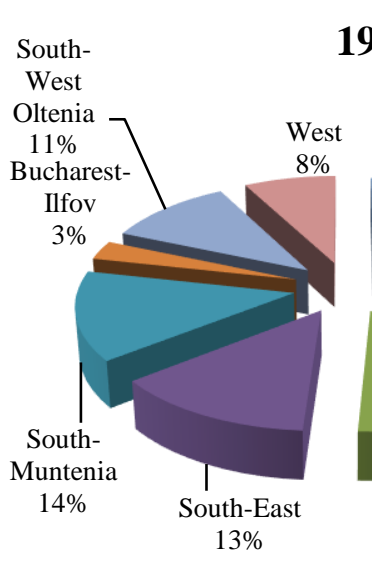

1997

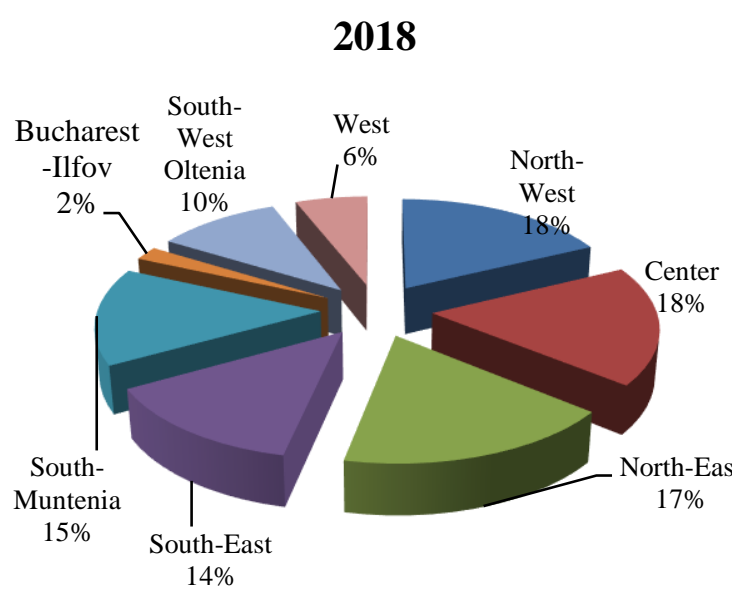

Figure 5. Evolutions of the share of students enrolled in pedagogical high schools by development regions in 1997 and 2018

\subsection{Students enrolled in high schools with artistic profile}

During the analyzed period, both the number of high schools with an artistic profile, as well as the students enrolled in the high schools with this profile, had a significantly different evolution from that of secondary pedagogical education. This evolution is characterized by three distinct periods: a period of upward growth (1998-2004), a crossing of a minimum (2004-2011) and a period of relative stability (2011-2018).

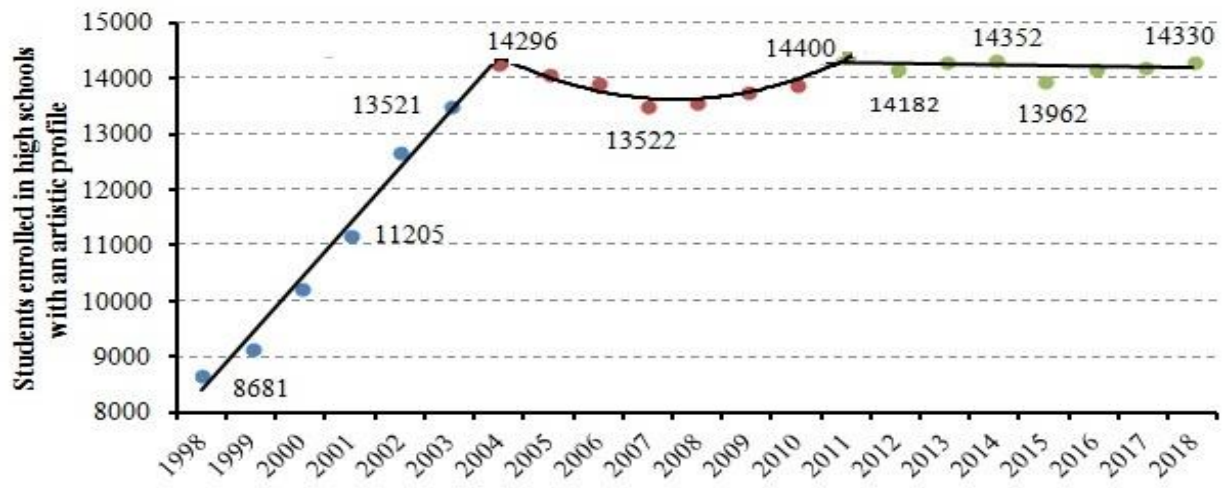

Figure 6. The characteristics of the evolution of the number of students enrolled in high schools with artistic profile between 1998-2018 
Taking these aspects into account, three evolution models were tested. The results obtained (Table 2) show that of the three models, only the first two are valid (statistically significant), for the third one (Model A3), given that Sig.F $=0.597>\alpha=0.05$, the hypothesis is accepted. null $\mathrm{HM}_{0}$.

Table 2. Results of testing the statistical significance of the evolution models of the number of students enrolled in high schools with artistic profile

\begin{tabular}{|c|c|c|c|c|c|c|c|c|c|}
\hline \multirow{2}{*}{ Model } & \multirow{2}{*}{ Period } & \multicolumn{4}{|c|}{ Models validation } & \multicolumn{4}{|c|}{ Regression validation } \\
\hline & & $\mathrm{R}$ & $\mathrm{R}^{2}$ & $\mathrm{~F}$ & Sig.F & \multicolumn{2}{|c|}{ Coefficients } & $\mathrm{t}$ & Sig.t \\
\hline \multirow{2}{*}{ A1 } & \multirow{2}{*}{ 1998-2004 } & \multirow{2}{*}{0.995} & \multirow{2}{*}{0.989} & \multirow{2}{*}{467.653} & \multirow{2}{*}{0.000} & $\mathrm{a}$ & 7402.14 & 35.81 & 0.000 \\
\hline & & & & & & $\mathrm{b}$ & 999.54 & 21.63 & 0.000 \\
\hline \multirow{3}{*}{ A2 } & \multirow{3}{*}{ 2004-2011 } & \multirow{3}{*}{0.949} & \multirow{3}{*}{0.861} & \multirow{3}{*}{22.691} & \multirow{3}{*}{0.003} & $\mathrm{a}$ & 14889.77 & 90.99 & 0.000 \\
\hline & & & & & & $b_{1}$ & -555.23 & -6.65 & 0.001 \\
\hline & & & & & & $\mathrm{b}_{2}$ & 60.83 & 6.72 & 0.001 \\
\hline \multirow{2}{*}{ A3 } & \multirow{2}{*}{ 2011-2018 } & \multirow{2}{*}{0.222} & \multirow{2}{*}{0.049} & \multirow{2}{*}{0.312} & \multirow{2}{*}{0.597} & $\mathrm{a}$ & 14305.04 & 123.74 & 0.000 \\
\hline & & & & & & $\mathrm{b}$ & -12.79 & -0.222 & 0.597 \\
\hline
\end{tabular}

Source: author calculations using SPSS

For the period 1998-2004, taking into account that $\mathrm{R} 2=0.989$, it turns out that the model offers a very good description of the evolution of the number of students enrolled in high schools with artistic profiles during this period. The model is:

$$
S A P_{1998-2004}(t)=7402.14+999.54 \cdot t+\varepsilon, \quad t_{1998}=1
$$

The value of parameter $b$ (the slope of the regression line) shows that in this period, the number of students enrolled in high schools with artistic increased by approximately 1000 students annually, reaching in 2004 to 14298 students, 64.68\% more than in 1998.

The second period, 2004-2011 shows a period of recoil, followed by a return of the number of students enrolled in this education profile. From an econometric point of view, the characteristic model of this period is a parabola of the form:

$$
S A P_{2004-2011}(t)=14889.77-555.23 \cdot t+60.83 \cdot t^{2}+\varepsilon, \quad t_{2004}=1
$$

The peak of the parabola is located in the year 2007 when the number of students enrolled in high schools with artistic profiles registers a minimum of 13552 students. Starting with 2008 there is a comeback so that in 2011 the number of students enrolled in this profile (14400 students) slightly exceeds (104 students) their number in 2004.

The third period (2011-2018) is characterized by alternating trends around a slightly decreasing trend, number of students enrolled in high schools with artistic profiles evolving between a maximum of 14400 students in 2011 and a minimum of 13962 students, in 2015.

To provide an intuitive picture of the evolution of the share of students enrolled in high schools with an artistic profile in the total number of students enrolled in secondary vocational education and their area of distribution at regional level, figure 7 was constructed, which captures the range of minimum and maximum throughout the analyzed period (1997-2018). 


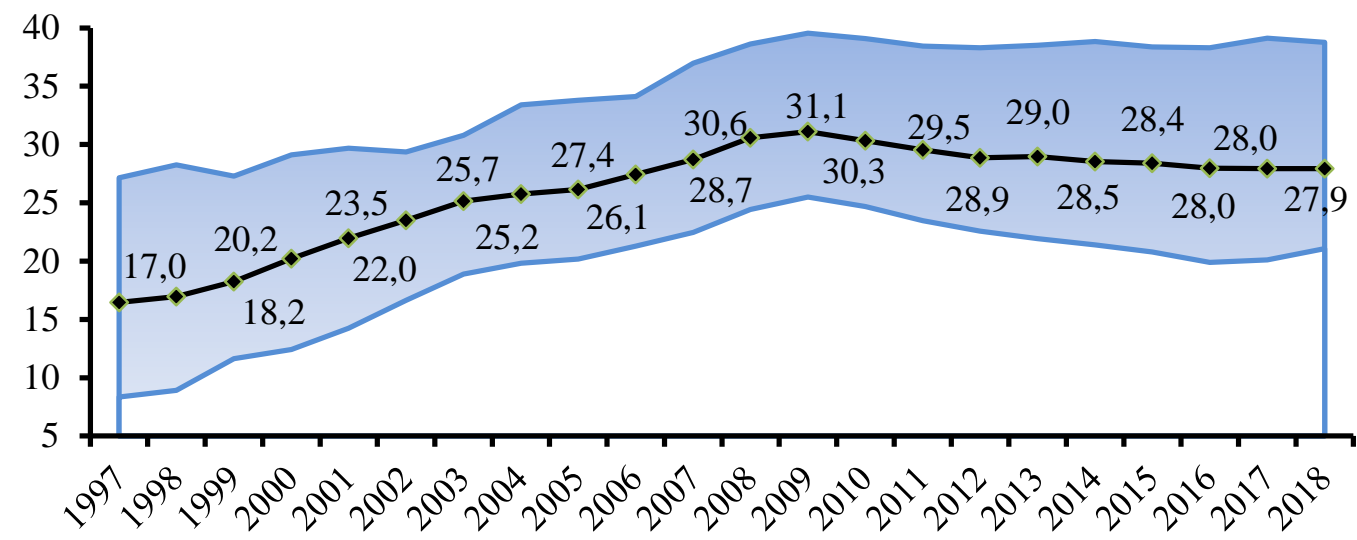

Figure 7. The evolution of the share of students enrolled in high schools with an artistic profile in the total number of students enrolled in secondary vocational education and their area of distribution at regional level

If in 1997, at the regional level, the highest share of students enrolled in high schools with an artistic profile in the total number of students enrolled in secondary vocational education was found in Bucharest-Ilfov (27.15\%), and the most low value in South-Muntenia (8.33\%), at the end of the period South-Muntenia recorded the lowest share $(21.07 \%)$, while the highest value is registered in the West Region (38.77\%). Therefore, during the period analyzed there are changes in the regions regarding the share of students enrolled in high schools with an artistic profile in the total number of students enrolled in secondary vocational education.

Compared to 2008, in 2018 there were no significant changes in the share of students enrolled in high schools with an artistic profile by high school types (figure 8). In 2018, the minimum values of the share of students enrolled in high schools with an artistic profile by high school types were registered at the high schools with plastic arts profile (46\%), and the maximum values were registered at the high schools with choregraphy profile ( $2 \%$ ). Between the two minimum and maximum values, the hierarchy the share of students enrolled in high schools with an artistic profile by high school types was: music (31\%), visual arts (14\%), theater (7\%).
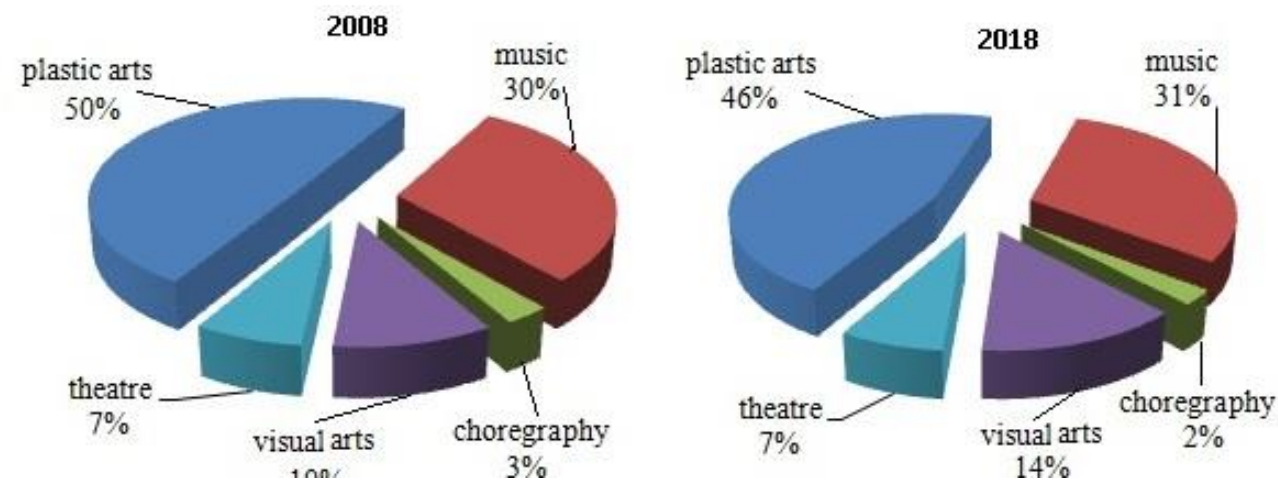

Figure 8. The share of students enrolled in high schools with an artistic profile by high school types in 2008 and 2018

\subsection{Students enrolled in high schools with a physical education and sports program}

The evolution of the number of students enrolled in high schools with a physical education and sports program is also characterized by three periods. 
Between 1998-2003, the evolution of students enrolled in high schools with a physical education and sports program shows an upward trend. Thus, compared to 1998 when a number of 10331 students was registered, in 2003 a number of 15068 students was registered, which represents an increase of 45.85\%. At the regional level, between 1998-2003, the highest value of Students enrolled in high schools with a physical education and sports program was registered in 2003 in the North-East region (2894 students), and the lowest in 1998 in Center Region (723 students).

Between 2004-2007, the evolution of students enrolled in high schools with a physical education and sports program shows a downward trend. Thus, compared to 2004 when a number of 15313 students was registered, in 2007 a number of 13863 students was registered, which means a decrease of 9.47\%. At the regional level, in 2004-2007, the highest value of students enrolled in high schools with a physical education and sports program was registered in 2004 in the North-East region (2952 students), and the lowest in 2007 in Center Region (1070 students).

Between 2008-2018, the evolution of students enrolled in high schools with a physical education and sports program shows an upward trend. Thus, compared to 2008 when a number of 13947 students was registered, in 2007 a number of 16982 students was registered, which represents an increase of $21.76 \%$. At the regional level, in 2008-2018, the highest value of students enrolled in high schools with a physical education and sports program was registered in 2018 in the Bucharest-Ilfov region (3195 students), and the lowest in 1998 in West Region (1034 students).

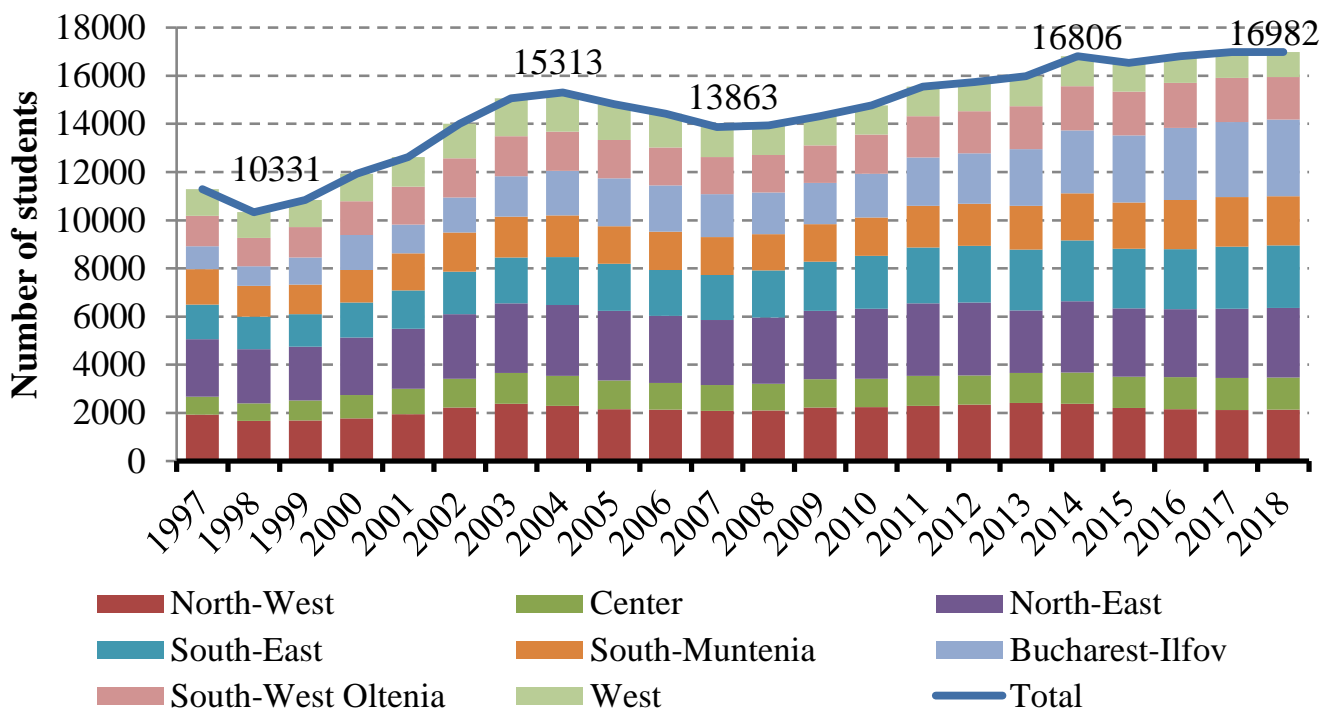

Figure 9. Evolutions of the number of students enrolled in high schools with a physical education and sports program, in 1997-2018 period

Between 1998 and 2004 the number of students increases from 10331 to 15313 students. It should be noted that the annual increase is approximately constant which led to a linear upward evolution of the form:

$$
\operatorname{SEPES}_{1998-2004}(t)=9081.2+966.94 \cdot t+\varepsilon, \quad t_{1998}=1
$$

After 2008, was recorded a regression of the number of students enrolled in high schools with a physical education and sports program, described by model (5), a regression that continues until 2008, so that in 2008 their number was $9.46 \%$ lower only in 2004.

$$
\operatorname{SEPES}_{2004-2008}(t)=15795.5-476.0 \cdot t+\varepsilon, \quad t_{2004}=1
$$

At the level of the school year 2008-2009, there is a slight stabilization around 13900 students, followed by an upward evolution (model 6) which is maintained until the end of the analyzed period. 
In 2018, a number of 16982 students enrolled in high schools with a physical education and sports program were registered.

$$
\operatorname{SEPES}_{2008-2018}(t)=13946.8+318.24 \cdot t+\varepsilon, \quad t_{2008}=1
$$

The results of the tests performed to verify the validity of the models (4-6) are presented in table 3. Given that all Sig.F values corresponding to the three models are lower than the significance threshold $(\alpha=0.05)$, as well as that the values of the ratio of correlation $(\mathrm{R})$ and of the coefficient of determination (R2) are very close to 1 , it results that the null hypothesis $\mathrm{HM}_{0}$ is rejected and, consequently, models (4-6) describe very well the evolution of number of students enrolled in high schools with a physical education and sports program, during the analyzed period.

Also, considering that on the one hand the Sig.t values are lower than the significance threshold, and on the other hand the confidence intervals for $95 \%$ confidence level do not include the value 0 , it follows that the values of the slope of the regression line (parameter b) are statistically significant.

Table 3. Test results of statistical significance of the evolution models of the number of students enrolled in high schools with a physical education and sports program.

\begin{tabular}{|c|c|c|c|c|c|c|c|c|c|r|r|}
\hline & & \multicolumn{4}{|c|}{ Model validation } & \multicolumn{6}{|c|}{ Regression validation } \\
\hline & Period & $\mathrm{R}$ & $\mathrm{R}$ & $\mathrm{F}$ & Sig.F & $\mathrm{b}$ & Std.Err & $\mathrm{t}$ & Sig.t & \multicolumn{2}{|c|}{$\begin{array}{c}\text { 95\% } \\
\text { Conf.Interval }\end{array}$} \\
\cline { 5 - 12 } & & & & & & & & & & Lower & Upper \\
\hline S1 & $1998-2004$ & 0.992 & 0.984 & 248.6 & 0.000 & 966.94 & 61.32 & 15.7 & 0.000 & 796.7 & 1137.2 \\
\hline S2 & $2004-2008$ & 0.998 & 0.997 & 612.6 & 0.002 & -476.0 & 19.10 & -24.9 & 0.002 & -558.1 & -393.8 \\
\hline S3 & $2008-2018$ & 0.958 & 0.981 & 101.3 & 0.000 & 318.24 & 31.62 & 10.1 & 0.000 & 246.7 & 389.8 \\
\hline
\end{tabular}

Source: author calculations using SPSS

Compared to 2008, in 2018 there were significant changes in the share of students enrolled in high schools with a physical education and sports program by regions (figure 8). In 2018, the minimum values of the share of students enrolled in high schools with a physical education and sports program were registered in the West region (6\%), and the maximum values were registered in Bucharest-Ilfov (19\%). Between the two minimum and maximum values, the hierarchy of students enrolled in high schools with a physical education and sports program by regions was: North-West (13\%), North-East $(17 \%)$, South-East (15\%), South-Muntenia (12\%), South-West Oltenia (10\%), Center $(8 \%)$. It is noted that the most pronounced changes were in the North-East region (a decrease by 5 percentage points) and Bucharest-Ilfov (an increase by 11 percentage points).

1998

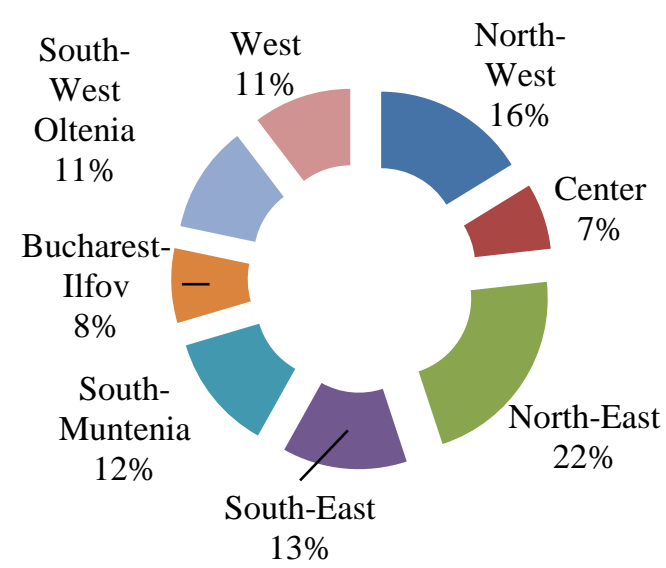

2018

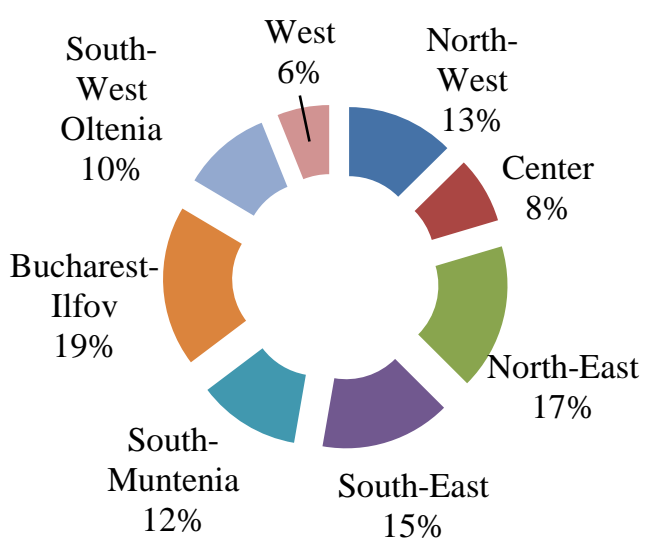

Figure 9. The share of students enrolled in high schools with a physical education and sports program in 1998 and 2018 


\subsection{Students enrolled in theological seminars}

During the analyzed period, after a slight increase until 2003, the number of students enrolled in theological highs decreases significantly in most of the development regions.

As can be seen from figure 10 and figure 1, the evolution of the number of students enrolled in the theological high schools is not similar to the one registered in the secondary vocational education.

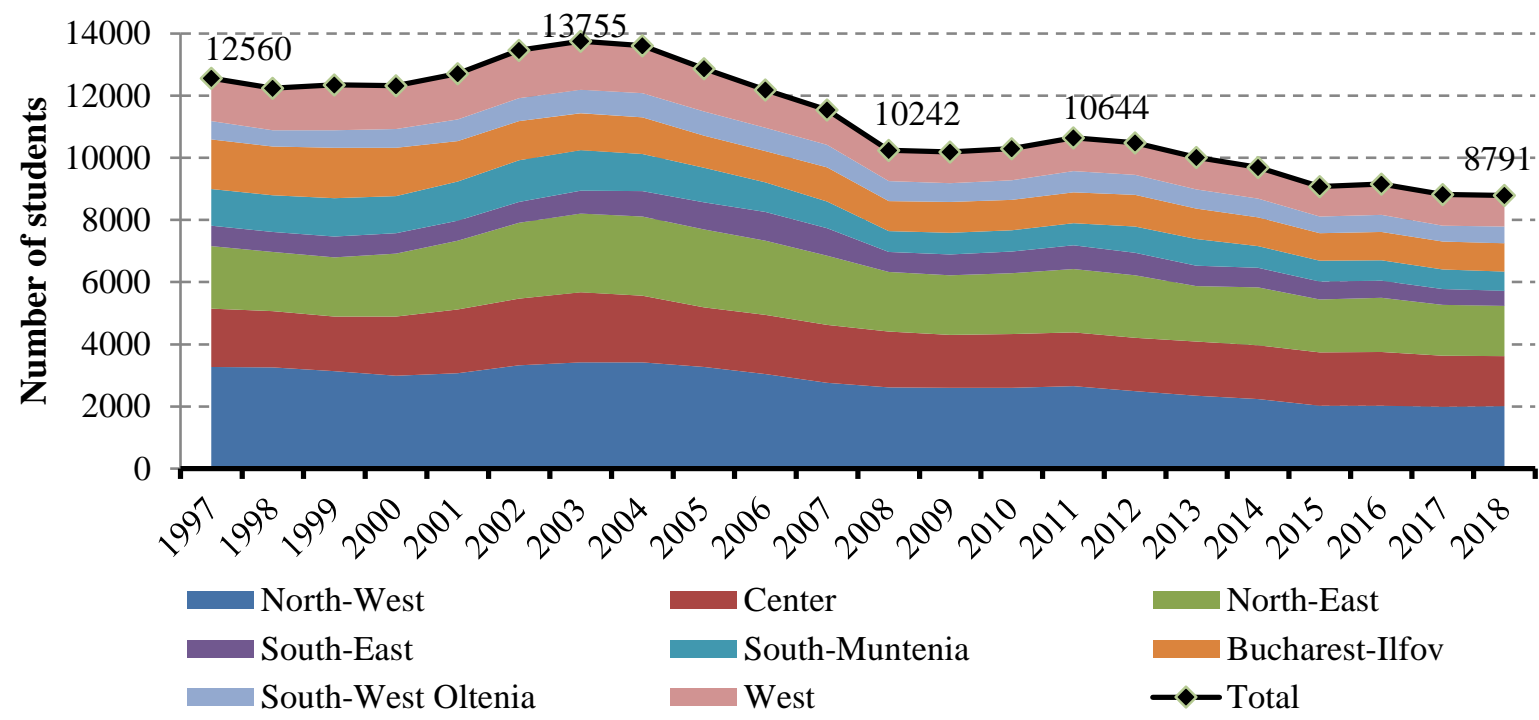

Figure 10. Evolutions of the number of students enrolled in theological seminars, in 1997-2018 period

From figure 10, it can be seen that after the period of increase (1997-2003), the number of students enrolled in theological seminars is on a downward trend both at national and regional level.

If in 1997, in the theological seminars were included 12560 students, at the end of the period analyzed, in 2018 there were 8791 students, representing a 70\% decrease, due on the one hand to the decrease of the school population, but especially to the reduced opportunities offered by the labor market.

In the regional profile, the evolution of the number of students enrolled in theological seminars had the same downward trend, as at national level. The West region is characterized by an increased level of theological seminars compared to the other regions, at the opposite pole being the South-East region.

Table 4. Results of testing the statistical significance of the evolution models of the number of students enrolled in theological seminars

\begin{tabular}{|c|c|c|c|c|c|c|c|c|c|}
\hline \multirow{2}{*}{ Model } & \multirow{2}{*}{ Period } & \multicolumn{4}{|c|}{ Models validation } & \multicolumn{4}{|c|}{ Regression validation } \\
\hline & & $\mathrm{R}$ & $\mathrm{R}^{2}$ & $\mathrm{~F}$ & Sig.F & \multicolumn{2}{|c|}{ Coefficients } & $\mathrm{t}$ & Sig.t \\
\hline \multirow{4}{*}{$\mathrm{T} 1$} & \multirow{4}{*}{$1997-2008$} & \multirow{4}{*}{0.967} & \multirow{4}{*}{0.935} & \multirow{4}{*}{38.601} & \multirow{4}{*}{0.000} & $\mathrm{a}$ & 12891.57 & 27.53 & 0.000 \\
\hline & & & & & & $\mathrm{b}_{1}$ & -635.13 & -2.12 & 0.067 \\
\hline & & & & & & $b_{2}$ & 194.68 & 3.71 & 0.006 \\
\hline & & & & & & $\mathrm{b}_{3}$ & -13.45 & -5.06 & 0.001 \\
\hline \multirow{2}{*}{$\mathrm{T} 2$} & \multirow{2}{*}{ 2009-2018 } & \multirow{2}{*}{0.908} & \multirow{2}{*}{0.824} & \multirow{2}{*}{37.405} & \multirow{2}{*}{0.000} & $\mathrm{a}$ & 10879.87 & 50.69 & 0.000 \\
\hline & & & & & & $\mathrm{b}$ & -211.52 & -6.12 & 0.000 \\
\hline
\end{tabular}

Source: author calculations using SPSS

At the level of Romania, the evolution in time of the number of students enrolled in theological seminars can be highlighted by two regression models (Table 3). The first model characterizes the 
evolution of the number of students enrolled in this profile during the period 1997-2008 and is of the form:

$$
\operatorname{STS}_{1997-2008}(t)=12891.57-635.13 \cdot t+194.68 \cdot t^{2}-13.45 \cdot t^{3}+\varepsilon, \quad t_{1997}=1
$$

With the exception of coefficient $b 1$, which is statistically significant for $90 \%$ confidence level $(\alpha=$ $0.10)$, the others are statistically significant for $95 \%$ confidence level $(\alpha=0.05)$. On the other hand, the value of the coefficient of determination $(\mathrm{R} 2=0.935)$ shows that model $(7)$ gives a very good description of the analyzed process, highlighting the two extreme points of the evolution of the number of students enrolled in theological seminars during this period. The first extreme point is a minimum, and corresponds to the needle 1998 (12242 students), and the second is a maximum, corresponding to 2003 (13733 students). The model further describes the downward evolution of the number of students enrolled in this profile until 2008, when their number reaches 10242 students.

The second period (2009-2018) corresponds to a linear model of form:

$$
S_{T S} 2009-2018(t)=10879.87-211.52 \cdot t+\varepsilon, \quad t_{2009}=1
$$

The model (7), by the value of parameter $b$ (slope of the regression line) shows that during this period, the number of students enrolled in theological seminars decreased annually with approximately 212 students, reaching in 2018 to 8791 students enrolled in high schools with this profile.

\subsection{Students enrolled in military high schools}

The evolution of students enrolled in military high schools in the period 1997-2018 registered an oscillating evolution both at national and regional level, characterized by two periods, respectively a period of decline (1997-2007) and a period of growth (2008-2018). It should be noted that the level reached in 2018 is well below the level recorded in 1997, 1972 students compared to 3061 students.

At the territorial level, there are significant differences regarding the number of students enrolled in military high schools in the period 1997-2018. (Figure 11)

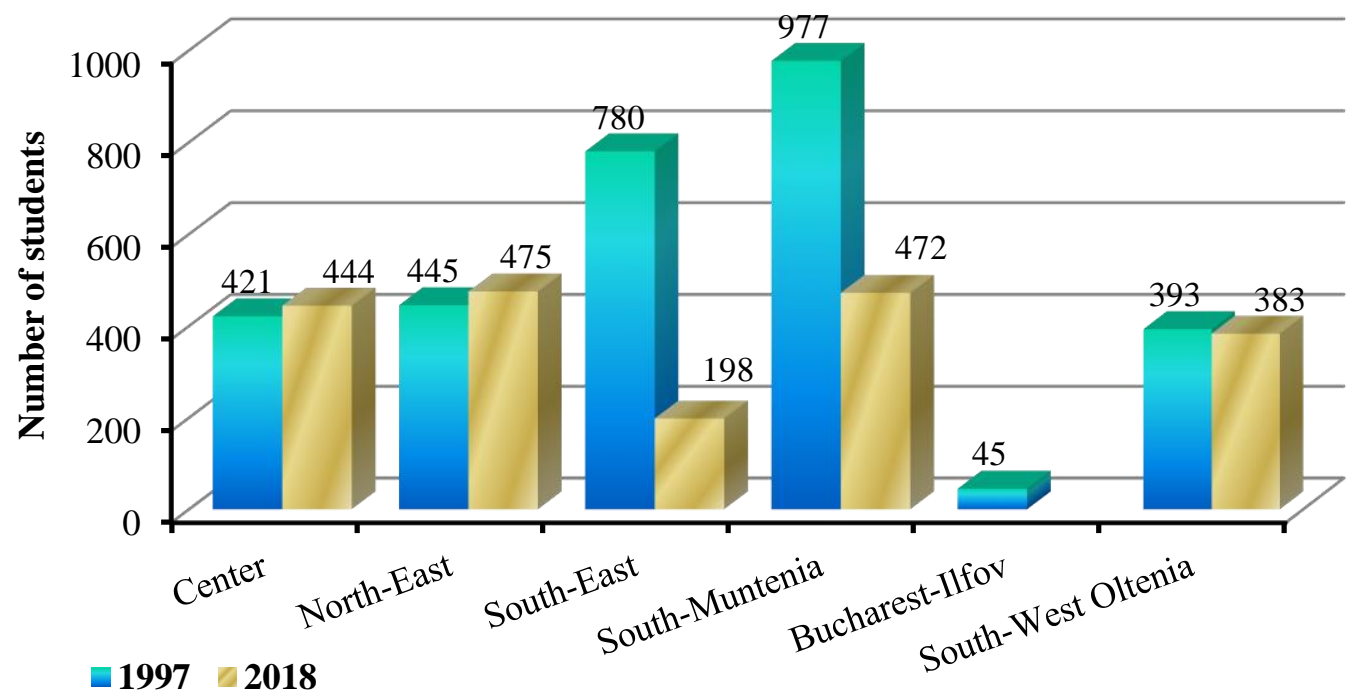

Figure 11. The number of students enrolled in military high school, in 1997 and 2018 at the level of the development regions

It is worth noting the significant decreases between the end and the beginning of the analyzed period in terms of Students enrolled in military high schools in the South-East regions $(-74.62 \%)$ and South-Muntenia (-51.69\%). In the rest of the other regions, except Bucharest-Ilfov and South-West Oltenia, there were small increases in the number of Students enrolled in military high schools. 


\section{Conclusions}

The secondary vocational education aims the specialization in various profiles (military, theological, sports, artistic and pedagogical) of all graduates in order to prepare for the labor market or to continue their studies.

The analysis of the number of students enrolled in secondary vocational education emphasizes that the demographic pressures, the reforms in the national education system and the opportunities offered by the labor market have produced structural changes at this level of education.

Between 1997-2018, the school population decreased by $17.8 \%$ for the level of secondary school education. Secondary vocational education was on the same downward trend, the school population enrolled in the vocational chain reaching in 2018 to be $4.5 \%$ lower than in 1997. For all the profiles in the vocational sector there were fluctuations during the analyzed period, with sub periods of decrease, especially at the beginning of the period analyzed, and sub periods of growth in the last years, but without reaching the level from the beginning of the period analyzed.

The structure by profiles of the students enrolled in secondary vocational education, in 2018 , reflects the choice of most students to study at the physical education and sports program $(33.0 \%$ of total vocational), following artistic profiles (27.9\%), pedagogical high education (18.2\%), theological seminars $(17.1 \%)$, military high school $(3.8 \%)$.

The tendency of increasing in the last years of the number of students in secondary vocational education has been influenced by the action of multiple factors, of which the most significant were the desire to continue the studies, the educational offer and the access to the labor market.

\section{References}

[1] Nistoreanu T and Răduț E 2010 Strategies on Preparation by Education Pre-University of Resources Work for the Correlation of Request with Offer on Labor Market Annals of University of Craiova - Economic Sciences Series 1 issue 38 pp. 134-142

[2] Dima I C, Ciurea Vl and Man M 2010 Positioning Of Pre-University Education Into the National System of Education of Romania Polish Journal of Management Studies 1 issue 1 pp. 102-110

[3] Badea, Liana and Țîrcă (Pociovalisteanu), Diana-Mihaela, (2014), Education and sustainable development - a connection for the future, Annals - Economy Series, 4, issue , p. 87-93.

[4] Andrusca, Andreea-Oana and Negura, Elena-Luiza, (2014), Education - Part of Sustainable Development, Knowledge Horizons - Economics, 6, issue 2, p. 170-173.

[5] Papakitsos, Evangelos C., (2016), Systemic modelling for relating labour market to vocational education, International Journal for Research in Vocational Education and Training (IJRVET), 3, issue 3, p. 166-184.

[6] Meer, Jonathan, (2005), Evidence on the Returns to Secondary Vocational Education, No 04014, Discussion Papers, Stanford Institute for Economic Policy Research.

[7] Agodini, Roberto, Uhl, Stacey and Novak, Timothy, Factors That Influence Participation in Secondary Vocational Education, Mathematica Policy Research Reports, Mathematica Policy Research.

[8] Silliman, Mikko and Virtanen, Hanna, (2019), Labor Market Returns to Vocational Secondary Education, No 65, ETLA Working Papers, The Research Institute of the Finnish Economy.

[9] Đurić, Igor, Đurić, Dejan and Živković, Predrag, (2013), Secondary vocational education in service of economic growth and society development, Economics of Agriculture, $\mathbf{6 0}$, issue 4, number 162031.

[10] Mihaela, Maer Matei Monica, Cristina, Mocanu and Ana-Maria, Zamfir, (2018), Educational paths in Romania: choosing general or vocational education, HOLISTICA - Journal of Business and Public Administration, 9, issue 2, p. 127-136. 
[11] Pavelescu F M (2018), Învățământul din România în perioada 1919-2017, Academia Română, Institutul Național de Cercetări Economice, p.18, available on-line at: http://www.studii-economice.ro/2018/seince181221.pdf

[12] ISE (2004) Antologia legilor învățământului românesc, Institutul de Științe ale Educației București, available on-line at: http://www.ise.ro/wp-content/uploads/2019/01/ANTOL_LEG_RO_2004.pdf

[13] National Insitute of Statistics, Romania, available on-line at http://www.insse.ro/cms/en

[14] International_Standard_Classification_of_Education, available on-line at: https://ec.europa.eu/eurostat/statisticsexplained/index.php/International_Standard_Classification_of_Education_\%28ISCED\%29

[15] National Insitute of Statistics, http://statistici.insse.ro:8077/tempo-online/\#/pages/tables/inssetable SCL103F - Enrolled population, by level of education, gender, macroregions, development regions and counties. Accesed on 2019 June 20

[16] Law of National Education ( Law 1/2011), Section 6, High school education, Art. 31. - (1) The Official Monitor of Romania, Year 179 (XXIII) - Nr. Monday, January 10, 2011 http://oldsite.edu.ro/index.php/articles/14847

[17] Zaharia Marian, Gogonea Rodica-Manuela - Econometrie. Elemente fundamentale, Editura Universitară, Bucureşti, 2009

[18] Ministerul Educației, Cercetării, Tineretului și Sportului Raport privind starea învăţământului preuniversitar din România 2011, available on-line at: https://www.edu.ro/sites/default/files/_fi\%C8\%99iere/Minister/2016/Transparenta/2016/ Raport_privind_starea_inv_preuniversitar.pdf 